

\title{
Isolation and characterization of mesotrione-degrading Bacillus sp. from soil
}

Isabelle Batisson, Olivier Crouzet, Pascale Pascale Besse, P. Besse-Hoggan

Besse-Hoggan, Martine Sancelme, Jean-François Mangot, Clarisse Mallet, Jacques Bohatier

\section{To cite this version:}

Isabelle Batisson, Olivier Crouzet, Pascale Pascale Besse, P. Besse-Hoggan Besse-Hoggan, Martine Sancelme, Jean-François Mangot, et al.. Isolation and characterization of mesotrionedegrading Bacillus sp. from soil. Environmental Pollution, 2009, 157 (157), pp.1195-1201. 10.1016/j.envpol.2008.12.009 . hal-00365544

\section{HAL Id: hal-00365544 \\ https://hal.science/hal-00365544}

Submitted on 3 Mar 2009

HAL is a multi-disciplinary open access archive for the deposit and dissemination of scientific research documents, whether they are published or not. The documents may come from teaching and research institutions in France or abroad, or from public or private research centers.
L'archive ouverte pluridisciplinaire HAL, est destinée au dépôt et à la diffusion de documents scientifiques de niveau recherche, publiés ou non, émanant des établissements d'enseignement et de recherche français ou étrangers, des laboratoires publics ou privés. 


\title{
Isolation and characterization of mesotrione-degrading Bacillus sp. from soil
}

\author{
Isabelle Batisson $^{\mathrm{a}, *}$, Olivier Crouzet ${ }^{\mathrm{a}}$, Pascale Besse-Hoggan ${ }^{\mathrm{b}}$, Martine Sancelme ${ }^{\mathrm{b}}$, \\ Jean-François Mangot ${ }^{\mathrm{a}}$, Clarisse Mallet ${ }^{\mathrm{a}}$, Jacques Bohatier ${ }^{\mathrm{a}}$ \\ a Laboratoire Microorganismes, Génome et Environnement, UMR 6023 CNRS, Université Blaise-Pascal, 63177 Aubière Cedex, France \\ b Laboratoire de Synthèse et Étude de Systèmes à Intérêt Biologique, UMR 6504 CNRS, Université Blaise-Pascal, 63177 Aubière Cedex, France
}

A Bacillus sp. strain isolated from soil was able to completely and rapidly biotransform the triketone herbicide mesotrione.

Keywords:

Mesotrione

Bacterial degradation

Soil

Bacillus sp.

2-Amino-4-methylsulfonylbenzoic acid

(AMBA)

\begin{abstract}
A B S T R A C T
Dissipation kinetics of mesotrione, a new triketone herbicide, sprayed on soil from Limagne (Puy-deDôme, France) showed that the soil microflora were able to biotransform it.

Bacteria from this soil were cultured in mineral salt solution supplemented with mesotrione as sole source of carbon for the isolation of mesotrione-degrading bacteria. The bacterial community structure of the enrichment cultures was analyzed by temporal temperature gradient gel electrophoresis (TTGE). The TTGE fingerprints revealed that mesotrione had an impact on bacterial community structure only at its highest concentrations and showed mesotrione-sensitive and mesotrione-adapted strains. Two adapted strains, identified as Bacillus sp. and Arthrobacter sp., were isolated by colony hybridization methods. Biodegradation assays showed that only the Bacillus sp. strain was able to completely and rapidly biotransform mesotrione. Among several metabolites formed, 2-amino-4-methylsulfonylbenzoic acid (AMBA) accumulated in the medium. Although sulcotrione has a chemical structure closely resembling that of mesotrione, the isolates were unable to degrade it.
\end{abstract}

\section{Introduction}

Mesotrione $\quad\{2$-(4-methylsulfonyl-2-nitrobenzoyl)1,3-cyclohenanedione\}, a member of the triketone family, is a new selective herbicide developed for use in maize culture as a substitute for atrazine (Mitchell et al., 2001). Agricultural application of this compound is steadily increasing. It offers pre- and post-emergence control of all the common broad-leaved weeds together with some of the annual grass weeds. Mesotrione is a herbicide chemically derived from a natural phytotoxin produced by the bottlebrush plant Callistemon citrinus (Mitchell et al., 2001). It was developed to minimize adverse effects on the environment. However, it may affect microbial activity and diversity in both soil and aquatic ecosystems (http://www.dive.afssa.fr/agritox/php/fiches.php). Indeed, recent work has shown that mesotrione exhibits moderate retention capacity in different soils (Dyson et al., 2002; Chaabane et al., 2008) and so may be leached to surface water.

Mesotrione was also classified as toxicologically dangerous for the environment by the EEC (Agritox data, 29/04/04). However, as it has not been in use for long (marketed in 2001 in Europe), little information about its fate and impact in the environment is

\footnotetext{
* Corresponding author. Tel.: +33 473407870; fax: +33 473407670 E-mail address: isabelle.batisson@univ-bpclermont.fr (I. Batisson).
}

available to date. Two mesotrione biotransformation products, 4-methylsulfonyl-2-nitrobenzoic acid (MNBA) and 2-amino-4methylsulfonylbenzoic acid (AMBA), have been described (Alferness and Wiebe, 2002). Recently, one mesotrione-degrading bacterial strain was isolated from cloud water (Durand et al., 2006a) and some new mesotrione metabolites have been identified (Durand et al., 2006b). It was shown that the AMBA biodegradation product had a higher toxicity than the parent compound (Bonnet et al., 2008). However, the fate of mesotrione and its biodegradation products in the environment have remained incompletely evaluated. Understanding the impact of mesotrione on the structure, diversity and function of soil microbial communities is thus of major environmental concern.

In this study, we report on the isolation and characterization of a Bacillus-degrading strain from an agricultural soil that permitted a rapid transformation of mesotrione. Its metabolic pathway was investigated.

\section{Materials and methods}

2.1. Sampling site and capacity of soil microbial communities to degrade mesotrione

Soil was collected from 15-year fallow land in Limagne (Puy-de-Dôme, France) that was plowed two years before sampling, planted with maize and never treated with mesotrione. The surface layer $(0-5 \mathrm{~cm})$ of the soil, which had a humidity level of $20 \%$, was air-dried, sieved $(\emptyset=2 \mathrm{~mm})$, homogenized and placed in flasks. 
Before isolating bacteria, the Limagne soil was tested for its capacity to biodegrade 10 times the agronomic dose of mesotrione $\left(4.5 \mathrm{mg} \mathrm{kg}^{-1}\right.$ dry soil weight). Mesotrione powder (Pestanal, purity 99.9\%; Fluka Riedel-de-Haën, Switzerland) was dissolved in distilled water and sprayed on $100 \mathrm{~g}$ of dry soil to obtain a final humidity of $20 \%$. The flasks were incubated in the dark at $22^{\circ} \mathrm{C}$. Degradation kinetics was measured for a 42-day incubation period. An abiotic control with autoclaved soil was also carried out under the same conditions. Two samples of each soil ( $5 \mathrm{~g})$ were taken at regular time intervals and placed in a centrifuge tube with distilled water $(20 \mathrm{~mL})$. The tubes were stirred on an orbital shaker at $50 \mathrm{rpm}$ at room temperature for $24 \mathrm{~h}$. After centrifugation at $12,500 \times \mathrm{g}$ for $15 \mathrm{~min}$, the supernatant was filtered on PVDF filters and analyzed by HPLC. No adsorption of mesotrione was observed on centrifuge tube and PVDF filters. The mesotrione recovery rate of the extraction procedure after incubation in the Limagne soil was $95.0 \pm 2.5 \%$ after $7 \mathrm{~h}$ of contact ( 10 replicates).

\subsection{Enrichment cultures in flasks and bacteria isolation}

To estimate the degradation capacity of the bacteria to mesotrione, $60 \mathrm{~g}$ of soil was added to $500 \mathrm{~mL}$ ( $10 \%$ dry w/v) of a mineral salt solution (MS) (Rousseaux et al. 2001). Mesotrione powder, added as the sole source of carbon, was directly dissolved in distilled water before adding the components of the MS medium. The fina mesotrione concentration in the enrichment medium was initially $25 \mathrm{mg} \mathrm{L}^{-1}$ and was doubled at three-week intervals in subsequent flasks, for a 77-day enrichmen culture, to reach a maximum of $100 \mathrm{mg} \mathrm{L}^{-1}$. To realize enrichment culture, $490 \mathrm{~mL}$ of fresh MS was inoculated with $10 \mathrm{~mL}$ of the precedent culture. The flasks were incubated at $28^{\circ} \mathrm{C}$ on an orbital shaker at $150 \mathrm{rpm}$ in darkness to avoid photolysis of mesotrione. The enrichment cultures were realized in duplicate. Cultures were sampled weekly for molecular analysis and bacteria isolation. A supernatant fraction and a soil particular fraction (pellet) of the cultures were separated by centrifuging $(10 \mathrm{~min}, 8000 \times \mathrm{g}$ ) before molecular analysis, except for the last enrichment step for which only a supernatant fraction was recovered, no more soil particles being present owing to the successive dilutions. To isolate the strains able to degrade mesotrione, MS agar (MSA) plates $\left(10 \mathrm{~g} \mathrm{~L}^{-1}\right.$ agar) were spread with $0.1 \mathrm{~mL}$ of a $20 \mathrm{mg} \mathrm{mL}^{-1}$ mesotrione solution in acetone. Other non-seeded MSA plates were used as negative controls. The acetone was then air-evaporated. Ten-fold serial dilutions of the weekly enrichment culture samples were spread on to the agar plates and incubated at $28^{\circ} \mathrm{C}$ in the dark for at least eight days.

\subsection{PCR amplification and temporal temperature gradient gel electrophoresis (TTGE)}

Bacterial genomic DNA was extracted by standard alkaline lysis method from $100 \mathrm{~mL}$ of bacterial cultures and was used as template to PCR amplify V6-V8 variable regions of 16S rDNA gene with the bacterium-specific forward primer GC968f and the reverse primer 1401r (MWG, Biotech, Table 1) as described by Pesce et al. (2006).

For cloning (see below), amplification was performed with the $968 \mathrm{f} / 1401 \mathrm{r}$ primer as follows: denaturation at $95^{\circ} \mathrm{C}$ for $15 \mathrm{~min}$, followed by 30 cycles of $97^{\circ} \mathrm{C}$ for $30 \mathrm{~s}, 62{ }^{\circ} \mathrm{C}$ for $30 \mathrm{~s}$ and $72{ }^{\circ} \mathrm{C}$ for $45 \mathrm{~s}$ per cycle, and a final extension step at $72{ }^{\circ} \mathrm{C}$

Table 1

Name and sequence of primers used in this study.

\begin{tabular}{|c|c|c|c|}
\hline Primer & Sequence $\left(5^{\prime}-3^{\prime}\right)$ & $\begin{array}{l}\text { Fragment } \\
\text { length (bp) }\end{array}$ & References \\
\hline$\overline{\text { GC-clamp }}$ & $\begin{array}{l}\text { CGCCCGCCGCGCGCGGCGGGCGG } \\
\text { GGCGGGGGCACGGGGGG }\end{array}$ & & \\
\hline $27 f$ & AGAGTITGATCCTGGCTCAG & 1484 & $\begin{array}{l}\text { (Weisburg } \\
\text { et al., 1991) }\end{array}$ \\
\hline $1492 \mathrm{r}$ & GGTTACCTTGTTACGACTT & & (Lane, 1991) \\
\hline $968 \mathrm{f}$ & AACGCGAAGAACCTTAC & 490 & (Heuer and \\
\hline $1401 \mathrm{r}$ & CGGTGTGTACAAGACCC & & Smalla, 1997) \\
\hline $2 \mathrm{~F}$ & GGACTAGAATGTGAGG & 67 & This study \\
\hline $2 \mathrm{R}$ & GCACCTTGTTTTGGGT & & This study \\
\hline $4 \mathrm{~F}$ & TACCCTTGACATGGCTG & 68 & This study \\
\hline $4 \mathrm{R}$ & GCACCTGTGTTCTGGT & & This study \\
\hline $5 \mathrm{~F}$ & CAGACTTGACATACAGT & 65 & This study \\
\hline $5 \mathrm{R}$ & GCACCTGTTCAGCAG & & This study \\
\hline $11 \mathrm{~F}$ & CTAGAGATAGAGCGTTCC & 150 & This study \\
\hline $11 \mathrm{R}$ & GTCACCTTAGAGTGCCC & & This study \\
\hline $12 \mathrm{~F}$ & AGCCCTTGACATGTCTA & 68 & This study \\
\hline $12 \mathrm{R}$ & GCACCTGTGTTCTAGG & & This study \\
\hline $13 \mathrm{~F}$ & TGGTCTTGACATGCAC & 69 & This study \\
\hline $13 \mathrm{R}$ & GCACCTGTGCAAAGC & & This study \\
\hline $15 \mathrm{~F}$ & CACCTTTGACATGTACG & 68 & This study \\
\hline $15 \mathrm{R}$ & GCACCTGTGTTACGGC & & This study \\
\hline $16 \mathrm{~F}$ & AAGGCTTGACATGGGC & 66 & This study \\
\hline $16 \mathrm{R}$ & CCACCTGTGAACCGG & & This study \\
\hline
\end{tabular}

The fragment length (bp) obtained after PCR amplification with the forward (F) and reverse $(R)$ primers is also indicated. for $10 \mathrm{~min}$. DNA was quantified using the DNA quantitation kit fluorescence assay (Sigma-Aldrich, France) according to the manufacturer's instructions.

The entire $16 \mathrm{~S}$ rDNA of isolated bacteria was amplified using the $27 \mathrm{f} / 1492 \mathrm{r}$ primers (Table 1). The program consisted of denaturation at $95^{\circ} \mathrm{C}$ for $15 \mathrm{~min}$ followed by 30 cycles at $94^{\circ} \mathrm{C}$ for $45 \mathrm{~s}, 53^{\circ} \mathrm{C}$ for $45 \mathrm{~s}$ and $72{ }^{\circ} \mathrm{C}$ for $45 \mathrm{~s}$ per cycle, and a final extension step for $10 \mathrm{~min}$ at $72^{\circ} \mathrm{C}$

TTGE analyses were performed using a DCode system (Bio-Rad, France) on $300 \mathrm{ng}$ of PCR products applied directly onto $8 \%(\mathrm{w} / \mathrm{v})$ polyacrylamide gels containing $7 \mathrm{M}$ urea, $1.25 \mathrm{X}$ Tris-acetate-EDTA (TAE). Runs were performed in 1.25X TAE at $68 \mathrm{~V}$ for $17 \mathrm{~h}$ with temperature ranging from $66^{\circ} \mathrm{C}$ to $69.7^{\circ} \mathrm{C}$ and a ramp rate of $0.2^{\circ} \mathrm{Ch}^{-1}$. After completion of electrophoresis, gels were stained for $1 \mathrm{~h}$ in the dark in a Gel Star nucleic acid gel stain bath (BMA) and photographed using a Versa Doc ${ }^{\mathrm{TM}}$ Imaging System (Bio-Rad) under UV transillumination.

\subsection{Clone library construction of single TTGE bands and sequencing}

Each DNA band of interest was excised from the polyacrylamide gel and small gel pieces were placed in sterilized vials. The samples underwent passive diffusion $\left(18 \mathrm{~h}\right.$ at $37^{\circ} \mathrm{C}$ ) and the DNA was recovered as described by Batisson et al. (2007). Five $\mu \mathrm{L}$ of eluted DNA was then used as template for a reamplification step using the GC968f/1401r primers, as described above. Purity of the PCR reamplification product was checked by rerunning an aliquot on TTGE gel. The purified DNA band was then amplified with $968 \mathrm{f} / 1401 \mathrm{r}$ primers as described above (Table 1) before being cloned into a pGEM-T-Easy vector (Promega, Charbonnières, France) to construct clone libraries. At least four clones were reamplified and rerun on TTGE gel for comparison with the parent band. A minimum of two cloned fragments that co-migrated with the original bands were bidirectionally sequenced (MWG - Biotech). Sequences were submitted to the National Center for Biotechnology Information (NCBI, BLASTn program (Altschul et al., 1997)) for species assignment and to the CHECK-CHIMERA program of the Ribosomal Database Project (RDP (Maidak et al., 1999)) to detect potential chimeric artifacts (Kopczynski et al., 1994).

Entire 16S rDNA sequences of the isolated strains were deposited in GenBank under Accession Nos: EU864320 (Mes11) and EU864321 (Mes16).

\subsection{Synthesis of digoxigenin-labeled DNA probe and colony hybridization}

Multiple alignments of partial 16S rDNA sequences performed on ClustalW software highlighted V6-V8 variable regions and made it possible to design specific primers for each strain (Table 1). Probes were PCR-labeled with digoxigenin (PCR DIG labeling mix, Roche Diagnostics, Meylan, France) according to the manufacturer's instructions. The PCR program was as follows: $95^{\circ} \mathrm{C}$ for $15 \mathrm{~min}$, then 30 cycles at $94^{\circ} \mathrm{C}$ for $30 \mathrm{~s}, 50^{\circ} \mathrm{C}$ for $30 \mathrm{~s}$ and $72^{\circ} \mathrm{C}$ for $30 \mathrm{~s}$ per cycle, and a final extension step at $72{ }^{\circ} \mathrm{C}$ for $7 \mathrm{~min}$, except for the $11 \mathrm{~F} / 11 \mathrm{R}$ primer pair where the elongation step was carried out at $54^{\circ} \mathrm{C}$ for $45 \mathrm{~s}$.

First, to determine the specificity of the probes, the different recombinant pGEM-T plasmids harboring the partial $16 \mathrm{~S}$ rDNA fragment were denatured at $95^{\circ} \mathrm{C}$ for $5 \mathrm{~min}$ and spotted onto positively-charged nylon membranes (Hybond- $\mathrm{N}^{+}$, Amersham International). DIG-labeled control DNA (Roche Diagnostics) was used as positive control for the dot-blot detection. The DNA was fixed by sandwiching the membrane between two pieces of Whatman $3 \mathrm{MM}$ paper and baking for $2 \mathrm{~h}$ in a vacuum at $80^{\circ} \mathrm{C}$. The membrane was then pre-hybridized, hybridized and revealed as described elsewhere (Batisson et al., 2007).

For bacteria isolation, colonies from the weekly samples of enrichment cultures spread on MSA plates were streaked in duplicate onto Luria-Bertani agar (LB-agar) plates and incubated at $28^{\circ} \mathrm{C}$ for $24-48 \mathrm{~h}$. Colonies of one LB-agar plate were replicated by placing a nylon membrane aseptically on top of the bacteria. The membranes carrying the colony lifts were treated as described by Heikinheimo et al. (2004) before being pre-hybridized, hybridized and visualized, as described above.

\subsection{Degradation capacity of mesotrione by the isolated strains}

To determine mesotrione degradation capacity, isolates were grown in $100 \mathrm{~mL}$ portions of trypcase-soy broth (bioMérieux, Marcy l'Etoile, France) in $500 \mathrm{~mL}$ flasks incubated at $28^{\circ} \mathrm{C}$ and $200 \mathrm{rpm}$. The cells $(200 \mathrm{~mL}$ of the culture) were harvested after $24 \mathrm{~h}$ of culture and centrifuged at $8000 \times \mathrm{g}$ for $15 \mathrm{~min}$ at $4{ }^{\circ} \mathrm{C}$. The bacterial pellet was washed first with an $\mathrm{NaCl}$ solution $\left(8 \mathrm{~g} \mathrm{~L}^{-1}\right)$ and then with Volvic mineral water. The resting cells were then resuspended in $100 \mathrm{~mL}$ of $0.1 \mathrm{mM}$ mesotrione solution and were incubated at $28^{\circ} \mathrm{C}$ in the dark on a rotary shaker $(200 \mathrm{rpm})$. Samples $(1 \mathrm{~mL})$ were regularly taken directly from the incubation medium and centrifuged at $10,000 \times \mathrm{g}$ for $5 \mathrm{~min}$. The supernatants were frozen until analysis by HPLC. The same procedure was followed for the experiment with $1 \mathrm{mM}$ mesotrione, except that the volume of the initial culture was $700 \mathrm{~mL}$. The abiotic controls consisted of preparations incubated under the same conditions with mesotrione alone or with autoclave-killed bacteria. All the degradation test cultures were realized in triplicate.

HPLC analyses were performed at $22^{\circ} \mathrm{C}$ using an Agilent 1100 chromatograph equipped with a diode array detector (DAD) and a fluorescent detector (FLD). A reversed-phase column (C-18 Zorbax Eclipse Plus column, $150 \mathrm{~mm} \times 4.6 \mathrm{~mm}$, $3.5 \mu \mathrm{m}$ ) was used at a flow rate of $1 \mathrm{~mL} \mathrm{~min}^{-1}$. The mobile phase was aqueous $\mathrm{H}_{3} \mathrm{PO}_{4}$ 
$(0.01 \% \mathrm{v} / \mathrm{v})(\mathrm{A}) / \mathrm{CH}_{3} \mathrm{CN}$ (B) used with a gradient method: $0-3 \mathrm{~min} 95 \% \mathrm{~A}-5 \% \mathrm{~B}$ $3-11 \mathrm{~min}$ from $5 \%$ to $85 \% \mathrm{~B}, 11-12 \mathrm{~min}$ from $85 \% \mathrm{~B}$ to $95 \% \mathrm{~B}, 12-13 \mathrm{~min}$ from 95 to $5 \% \mathrm{~B}$ and $13-16$ min $95 \% \mathrm{~A}-5 \% \mathrm{~B}$. The injection volume was $10 \mu \mathrm{L}$ and the detectors were set at $\lambda=254 \mathrm{~nm}(\mathrm{DAD}), \lambda_{\mathrm{exc}}=220 \mathrm{~nm}$, and $\lambda_{\mathrm{em}}=430 \mathrm{~nm}$ (FLD). The DAD-UV and FLD spectra were compared with those of standards (mesotrione, AMBA, MNBA sulcotrione) recorded in the mobile phase $\mathrm{pH}$ range.

\section{Results}

\subsection{Capacity of microbial communities from Limagne soil to} degrade mesotrione

To check that the microflora of the soil were able to degrade mesotrione, dissipation kinetics was measured after a contamination of 10 times the agronomic dose of the molecule. A similar experiment was carried out with autoclaved soil (abiotic control) (Fig. 1). A progressive decrease in mesotrione along the 42-day incubation time was observed, resulting in the dissipation of around $50 \%$ of the compound by microbial communities. The dissipation rate in the autoclaved soil was only of $10 \%$ for the same period and corresponded to adsorption process. This evidenced the capacity of this soil to biotransform mesotrione. Moreover, AMBA, a known-metabolite of mesotrione, was formed during this experiment and detected in the soil samples (data not shown).

\subsection{Enrichment of a bacterial culture that degrades mesotrione}

To monitor bacterial population diversity over time and assess the impact of mesotrione on these communities, the V6-V8 16S rDNA amplification products from weekly enrichment culture samples were analyzed by TTGE (Fig. 2). At day 0, numerous bands were detected in both supernatant and pellet fractions on TTGE fingerprints (Fig. 2A). Only temporal modifications were detected during the 21-day experiment with $25 \mathrm{mg} \mathrm{L}^{-1}$ of mesotrione in the supernatant and pellet fraction, but no major differences were observed between the control $(\mathrm{C})$ and mesotrione-treated $(\mathrm{M})$ flasks.

When the cultures were supplemented with $50 \mathrm{mg} \mathrm{L}^{-1}$ of mesotrione (Fig. 2B), the TTGE fingerprints showed a lower bacterial diversity compared with the first enrichment step $\left(25 \mathrm{mg} \mathrm{L}^{-1}\right.$ mesotrione). Although no major variations were observed in the pellet fraction, the control flasks were clearly separated from

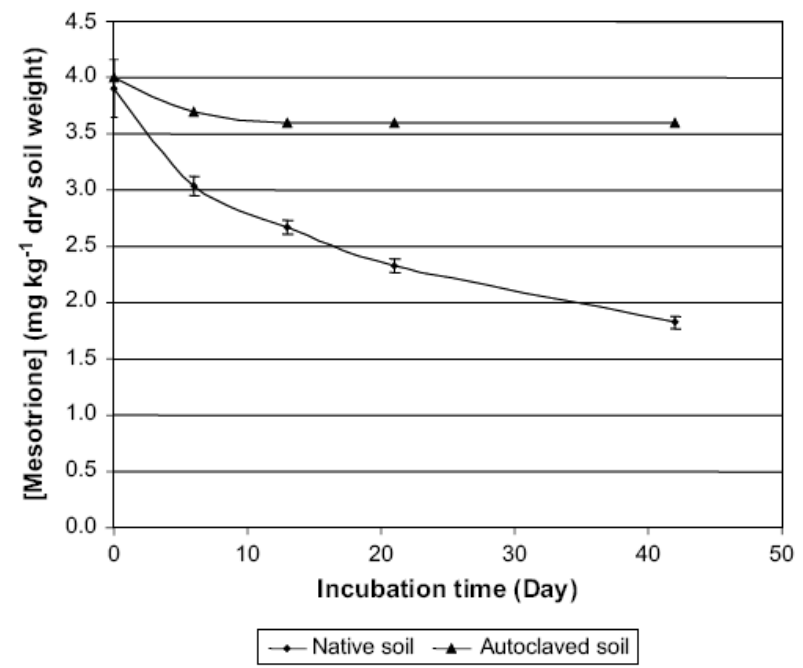

Fig. 1. Mean $( \pm$ s.d.) degradation of the mesotrione by microbial communities of Limagne soil after application of 10 times the agronomic dose $\left(4.5 \mathrm{mg} \mathrm{kg}^{-1} \mathrm{dry}\right.$ soil weight). Degradation assays were performed at $28^{\circ} \mathrm{C}$ in the dark. Autoclaved soil was used as negative control for biodegradation. mesotrione-treated flasks in the supernatant fractions. A different band pattern was highlighted from day 28 to day 42 , with bands found only in the mesotrione-treated flasks compared with controls (e.g. bands 2 and 4, Fig. 2B). Other bands were ubiquitous and were present equally in all flasks irrespective of the culture conditions (e.g. band 11).

These differences between environmental conditions of cultures in flasks (treated versus control) were confirmed when cultures were supplemented with $100 \mathrm{mg} \mathrm{L}^{-1}$ of mesotrione (Fig. 2C). Bands only found or predominant in mesotrione-treated flasks and absent in controls (bands $5,12,13,15,16$ ) and bands only visible or predominant in untreated flasks (bands $10,17,19,20$ ) became more clearly apparent (Fig. 2C).

\subsection{Identification and isolation of mesotrione-degrading strains}

Bands of interest (Fig. 2) corresponding to ubiquitous (e.g. band 11 ), mesotrione sensible (e.g. bands $10,17,19,20$ ) or mesotrioneadapted bands (e.g. bands $2,4,5,12,13,15,16$ ) were excised and sequenced. The nearest neighbor and phylogenetic group of each sequence are listed in Table 2

To isolate mesotrione-degrading bacterial strains, the enrichment cultures were plated weekly on either mesotrione-supplemented or control MSA. There were no significant differences between plates in cell density and colony morphology. Since it was impossible to distinguish between bacteria in control and contaminated cultures, a colony hybridization method was used. Sequences obtained from the different bands of interest were thus aligned to design primers targeting variable regions of each strain (Table 1 ) and so generate probes. The cross-reactivity of the probes against the V6-V8 variable regions of $16 \mathrm{~S}$ rDNA clone library obtained in this study was tested and showed high specificity for each probe. Only two colonies corresponding to bands 11 and 16 (Fig. 2) were successfully isolated. They were named strain Mes11 and Mes16, respectively. Their entire $16 \mathrm{~S}$ rDNA was then sequenced using the 27f/1492r primer couple (Table 1) and aligned using the BLASTn program. The results matched those obtained with the V6-V8 phylogenetic affiliation of these strains (Table 2) and confirmed that strain Mes 11 and Mes 16 were 99\% similar to Bacillus sp. and Arthrobacter sp., respectively.

\subsection{Capacity of the isolates to degrade mesotrione}

We investigated the capacity of each isolate to degrade $0.1-1 \mathrm{mM}$ mesotrione in resting cells. The kinetics of degradation is illustrated in Fig. 3. After $50 \mathrm{~h}$ of incubation, the Arthrobacter sp. strain (Mes 16) did not give rise to $0.1 \mathrm{mM}$ mesotrione degradation (Fig. 3A). Degradation assays with lower concentrations of mesotrione (down to $2 \mathrm{mg} \mathrm{L}^{-1}=6 \mu \mathrm{M}$ ) were also unsuccessful (data not shown). By contrast, the Bacillus sp. isolate (Mes11) completely degraded the mesotrione after $50 \mathrm{~h}$ and $24 \mathrm{~h}$ of incubation with $0.1 \mathrm{mM}$ and $1 \mathrm{mM}$, respectively (Fig. $3 \mathrm{~A}$ and B). Furthermore, in the experiment with $1 \mathrm{mM}$ of mesotrione, several metabolites were detected by HPLC during the biodegradation. One was particularly interesting as it accumulated in the medium. This metabolite was identified as AMBA by comparison with the standard. The AMBA metabolite appeared clearly after $3 \mathrm{~h}$ of incubation and reached a concentration of about $0.1 \mathrm{mM}$ at the plateau phase that persisted up to $60 \mathrm{~h}$ (Fig. 3B). From $60 \mathrm{~h}$ to the end of the experiment $(120 \mathrm{~h}$ ), a new increase of AMBA up to a maximum of $0.3 \mathrm{mM}$ was observed. No disappearance of mesotrione was observed with controls containing the pesticide alone (data not shown) or autoclave-killed bacteria (Fig. 3B). Two other metabolites were identified by comparison with metabolites previously described with another Bacillus strain (Durand et al., 2006b): the hydroxylamino derivative of mesotrione 1 and the benzisoxazol-3-ol 2 (Fig. 4). 


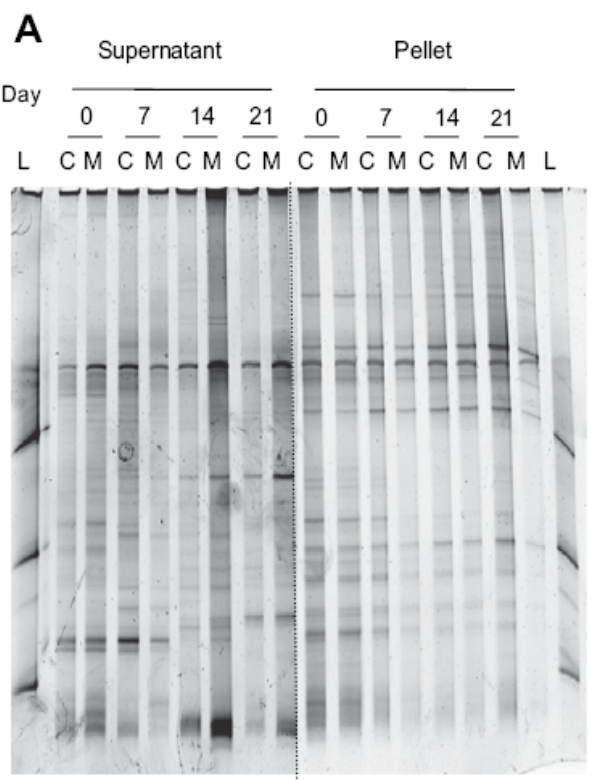

$\mathrm{M}: 25 \mathrm{mg} \mathrm{L}^{-1}$ mesortione
$\mathrm{C}:$ no mesotrione
B

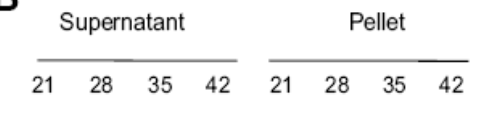

$\overline{C M} \overline{C M} \overline{C M} \overline{C M C M C M C M L}$

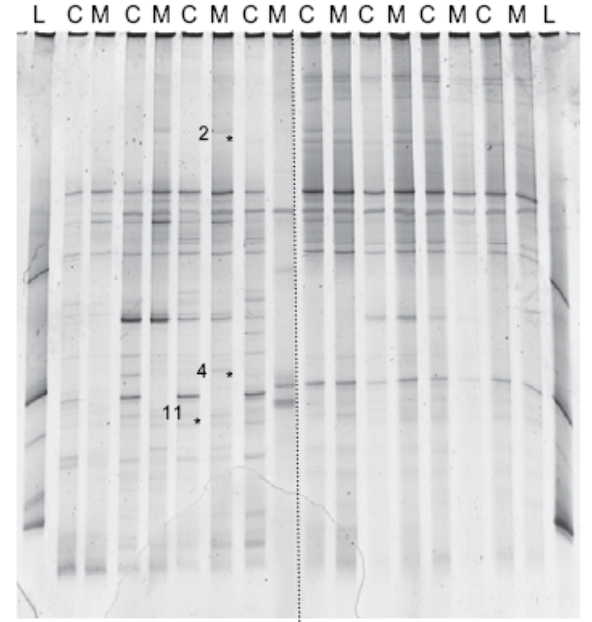

$\mathrm{M}: 50 \mathrm{mg} \mathrm{L}^{-1}$ mesortione

C : no mesotrione
C

Supernatant

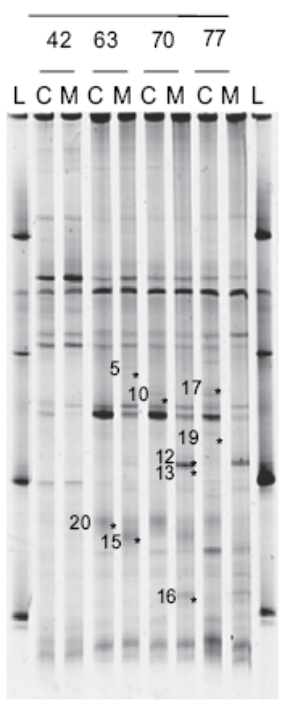

$\mathrm{M}: 100 \mathrm{mg} \mathrm{L}^{-1}$ mesotrione

C: no mesotrione

Fig. 2. Study of bacterial community evolution by TTGE analysis of V6-V8 $16 \mathrm{~S}$ rDNA fragments in control (C; without mesotrione) and mesotrione-treated (M) enrichment cultures inoculated with Limagne soil from day 0 to day 77 . Two enrichment steps of 21 days (for $25 \mathrm{mg} \mathrm{L}^{-1}$ (A) and $50 \mathrm{mg} \mathrm{L}^{-1}$ (B) mesotrione) and one of 35 days (for $100 \mathrm{mg} \mathrm{L}^{-1}$ (C) mesotrione) were carried out. Numbers represent the bands of interest that were excised from the gel, purified and sequenced. L: Ladder composed of Alcaligenes faecalis, Kurthia zopfii, Stenotrophomonas maltophilia and Flavobacterium aquatile.

The capacity of Bacillus sp. and Arthrobacter sp. to degrade $0.1 \mathrm{mM}$ of sulcotrione, another triketone family member, was also tested under the same conditions, but no degradation was observed (data not shown).

\section{Discussion}

\subsection{Enrichment cultures with mesotrione}

Although the MS medium used for enrichment cultures did not contain a carbon source (Rousseaux et al., 2001), bacterial growth was observed in control flasks similar to that of the mesotrione-treated flasks (data not shown). The same observation has already been made for the isolation of other pesticidedegradation bacteria (Turnbull et al., 2001; Batisson et al., 2007). In our study, the bacterial growth in the control flask could be explained by the supply of some organic matter and nutrient sources in the initial soil inocula and could also explain the bacterial background observed on MSA plates. Carbon sources could also be supplied by impurities in the agar (Cullington and Walker, 1999; El Fantroussi, 2000; Turnbull et al., 2001; Dejonghe et al., 2003).

Table 2

Similarity to nearest neighbors and closest phylogenetic affiliation of TTGE band sequences detected in enrichment cultures based on BLASTn comparison with the GenBank database.

\begin{tabular}{|c|c|c|c|c|c|}
\hline \multirow[t]{2}{*}{ Band } & \multicolumn{3}{|c|}{ Nearest neighbor } & \multirow[t]{2}{*}{ Phylogenetic group, Class - Family } & \multirow[t]{2}{*}{ References } \\
\hline & Similarity (\%) & Species & Accession number & & \\
\hline$\overline{2}$ & 99 & [Uncultured soil bacterium clone DS-249] & AY289362.1 & Acidobacteria - Acidobacteriaceae & Zhou et al. (2003) \\
\hline 4 & 97 & [Herbaspirillum sp. YM23] & EU418729 & $\beta$-Proteobacteria-Oxalobacteraceae & Sun, Unpublished \\
\hline 5 & 91 & [Uncultured bacterium clone OTU289] & DQ684283.1 & Chlamydia - Parachlamydiaceae & LeBlanc et al. (2007) \\
\hline \multirow[t]{2}{*}{11} & 99 & [Bacillus sp. HNL20] & EU373361.1 & Bacilli - Bacillaceae & Cho et al., Unpublished \\
\hline & 99 & \{Bacillus sp. G3DM-48\} & EU037283.1 & Bacilli - Bacillaceae & Desai et al., Unpublished \\
\hline 12 & 99 & [Uncultured eubacterium OCG9] & AB047120.1 & $\alpha$-Proteobacteria - unclassified Rhizobiales & Watanabe et al. (2001) \\
\hline 13 & 96 & $\begin{array}{l}\text { [Uncultured Verrucomicrobia bacterium } \\
\text { clone AKYH1486] }\end{array}$ & AY922120 & Verrucomicrobiae - Verrucomicrobiaceae & Tringe et al. (2005) \\
\hline 15 & 99 & [Acidovorax sp. NO-1] & EU521706.1 & $\beta$-Proteobacteria-Comamonadaceae & Fan et al., Unpublished \\
\hline \multirow[t]{2}{*}{16} & 100 & [Uncultured bacterium clone OTU506] & DQ684500.1 & Actinobacteria - Micrococcaceae & LeBlanc et al. (2007) \\
\hline & 99 & $\{$ Arthrobacter sp.\} & DQ158001.1 & Actinobacteria - Micrococcaceae & $\begin{array}{l}\text { Nakatsu and Beasley, } \\
\text { Unpublished }\end{array}$ \\
\hline 10 & 99 & [Unidentified bacterium wb1_A01] & AF317740 & $\gamma$ Proteobacteria - Pseudomonadaceae & Holmes et al. (2001) \\
\hline 17 & 97 & [Uncultured bacterium clone OTU001] & DQ683995.1 & Chlamydiae - Parachlamydiaceae & LeBlanc et al. (2007) \\
\hline 19 & 94 & [Uncultured bacterium clone L3B_344] & EF551894.1 & $\alpha$-Proteobacteria - Phyllobacteriaceae & Hiibel et al., Unpublished \\
\hline 20 & 99 & [Acidovorax facilis strain LMG 2193] & EU024133.1 & $\beta$-Proteobacteria - Comamonadaceae & Ait Tayeb et al. (2008) \\
\hline
\end{tabular}

[ ]: Alignment of V6-V8 16S rDNA sequences; \{ \}: alignment of entire 16S rDNA sequences. 

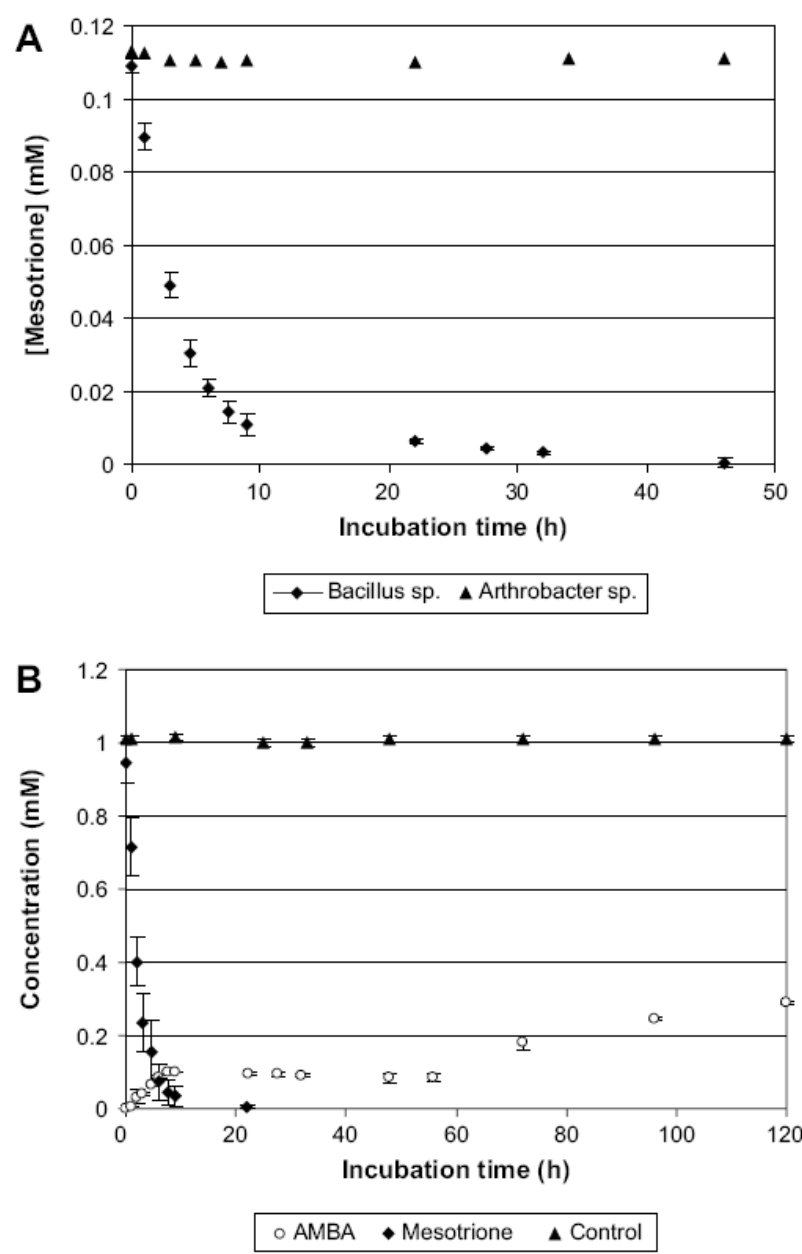

Fig. 3. Degradation assays with resting cells. (A) Degradation of $0.1 \mathrm{mM}$ mesotrione by Bacillus sp. and Arthrobacter sp. (B) Time courses of mesotrione (1 mM) and AMBA during biodegradation by Bacillus sp. Abiotic control of mesotrione corresponds to the dissipation observed with autoclaved bacteria. Assays were performed at $28^{\circ} \mathrm{C}$ in the dark. Errors bars represent the mean ( \pm s.d.) of three independent experiments.

\subsection{Bacterial culture response to mesotrione exposure}

Unlike the spreading of bacteria on agar plates, the TTGE approach highlighted some differences in bacterial populations of control and mesotrione-treated cultures. We were able to reveal shifts in the dominant bacterial community with regard to natural populations (day 0 ) and between control and mesotrione-treated flasks (Fig. 2).

After only seven days of enrichment culture, the shift of the bacterial community observed in both treated and control flasks compared with the initial bacterial community was probably due to the phase of acclimatization to the experimental conditions and/or the unculturability of some bacteria. These observations were confirmed after the second week of enrichment culture (Fig. 2). Effects of mesotrione on the bacterial community were only detected seven days after treatment with $50 \mathrm{mg} \mathrm{L}^{-1}$ of herbicide (day 28), suggesting that a latency phase was required to allow induction of specific enzyme systems in response to the organic pollution pressure (Četkauskaité et al., 1998). Thereafter and for higher concentrations of mesotrione, bands that were maintained, changed in intensity or appeared only in the mesotrione exposure flasks were interpreted as corresponding to bacterial species potentially able to use this molecule for their growth as observed in previous studies (El Fantroussi et al., 1999; El Fantroussi, 2000; Crecchio et al., 2001; Bending et al., 2003; Pesce et al., 2006; Batisson et al., 2007).

\subsection{Identification and isolation of bacteria adapted to mesotrione}

TTGE bands of interest were sequenced and affiliated to diverse phylogenetic groups (Table 2). Strains corresponding to bands 2 and 13 were affiliated to bacteria isolated from natural soil or water environmental samples (Zhou et al., 2003; Tringe et al., 2005). However, band 13 also showed $95 \%$ similarity with an uncultured Verrucomicrobia bacterium encountered in diuron-contaminated microcosms (Pesce et al., 2008) suggesting that the Verrucomicrobia bacterial group might play an important role in the ecosystem after chemical pollutant exposure. Nearest neighbors of strains corresponding to bands 5 and 12 were uncultured bacteria found in soil rhizosphere communities altered by the culture of genetically modified plants (LeBlanc et al., 2007) and oil-contaminated water (Watanabe et al., 2001), respectively, emphasizing the capacity of Chlamydia and $\alpha$-Proteobacteria to adapt to modifications of their environment. Furthermore, 16S rDNA corresponding to band 5 was also $90 \%$ similar to that of Chlamydia found in phenylurea herbicide-contaminated water (Pesce et al., 2008), likewise showing the capacity of these strains to acclimatize to organic compound pollution. Bands 4 and 15 sequences showed high similarity with bacteria isolated from a copper mine (Sun, unpublished data; Accession No. EU418729) and from a gold mine contaminated with arsenite (Fan et al., unpublished data; Accession No. EU521706). Two strains, showing 99\% similarities to Arthrobacter sp. (band 16) and Bacillus sp. (band 11), were successfully isolated from our enrichment cultures with mesotrione. They were also encountered in soil microcosms contaminated with xylene and chromate (Nakatsu and Beasley, unpublished data; Accession No. DQ158001) and in long-term chromium-contaminated sediments (Desai et al., unpublished data; Accession No. EU037283), respectively. Arthrobacter sp. and Bacillus sp. were also isolated from a microcosmenrichment cultures supplemented with chloropicrin and metam sodium (Ibekwe et al., 2004), suggesting a resistance and/or degradation capacity of these strains for numerous xenobiotics.

Despite many attempts, no other strains adapted to mesotrione were isolated from the MSA plates. This could be due to a loss of degradation capacity on solid media (El Fantroussi, 2000).

\subsection{Biodegradation of mesotrione}

Pure-culture mesotrione degradation experiments in resting cells indicated that the strain Mes16, although responsible for a clearly visible band specific to treated flasks (Fig. 2C), was not able to degrade mesotrione (Fig. 3A). This result denotes that mesotrione had no toxic effect on this strain and suggests that the Mes16 isolate may require a synergistic interaction with other bacteria to degrade mesotrione. When isolate Mes 11 was tested, we observed that within the first $24 \mathrm{~h}$ of incubation, $1 \mathrm{mM}$ mesotrione was completely degraded (Fig. 3B). It was not surprising to find mesotrione-degrading bacteria in our soil since the presence of specific microflora able to degrade triketone had been already found in soil free of mesotrione treatment (Chaabane et al., 2008). However, a difference in percentage and rate of mesotrione degradation was observed between native soil and liquid culture that reflects the different environmental conditions of the bacteria (no mesotrioneadapted microbial communities in soil with complex organic matter available versus mesotrione-adapted bacteria in pure liquid culture with only mesotrione as the sole carbon source). 


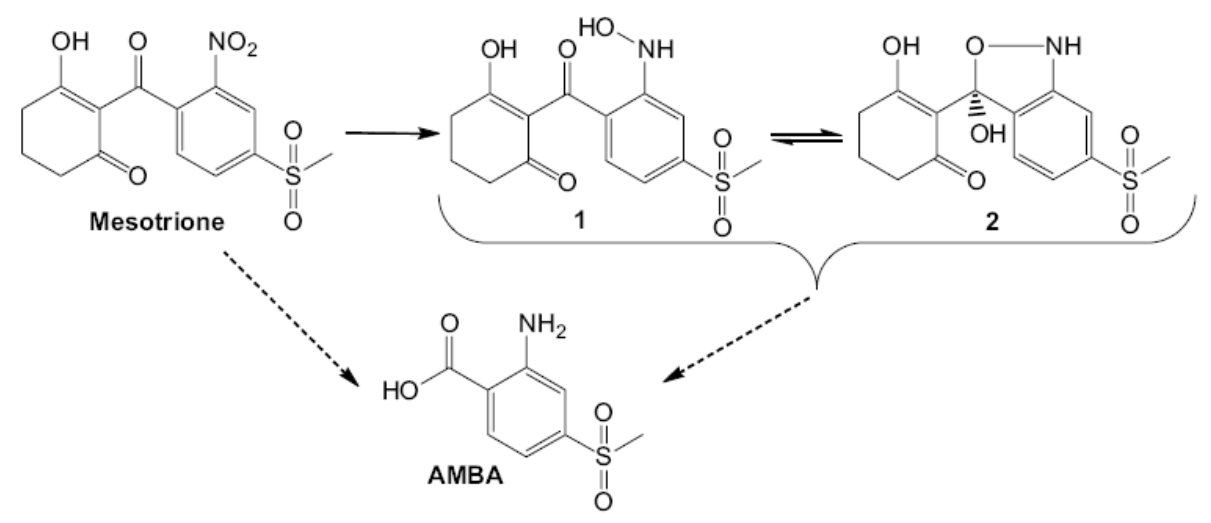

Fig. 4. Proposed scheme of mesotrione biodegradation by Bacillus sp.

This biodegradation of mesotrione with Mes 11 led to the formation of several detected metabolites. The concentration of some of these reached a maximum and then decreased. Two of them have already been identified during mesotrione degradation by the Bacillus sp. 3B6 strain (Durand et al., 2006b) and were produced in the same order of magnitude by the Mes 11 strain: an hydroxylamino derivative 1 obtained by reduction of the nitro group of mesotrione and a cyclized compound 2 (isoxazolol), formed by an intramolecular cyclization of the hydroxyl moiety of the hydroxylamine on the carbonyl group (Fig. 4). Another metabolite, which accumulated in the medium, was identified as AMBA by comparison of its retention time and UV spectrum with those of a standard. Contrary to what was observed by Alferness and Wiebe (2002), no MNBA degradation product could be detected after mesotrione degradation by the Mes11 strain. This result is in accordance with those obtained with the Bacillus sp. strain 3B6 (Durand et al., 2006a). This 3B6 strain was also able to completely and rapidly degrade mesotrione and led to the formation of five metabolites, three of them (AMBA, 1 and 2 ) being also produced by the Mes11 strain. This result highlights the important role of these Bacillus species in triketone degradation. Nevertheless, with both these Bacillus strains, AMBA accumulated in the medium, indicating that mesotrione was not completely mineralized under the conditions used. The kinetics of AMBA appearance displayed two steps: a first increase of AMBA concentration to a plateau within the first hours of incubation followed by a second higher increase after $60 \mathrm{~h}$ (Fig. 3B). This could be the result of a two-pathway degradation mechanism as suggested by the mesotrione degradation model proposed by Durand et al. (2006b): (i) a minor pathway leading almost directly to AMBA by an oxidative cleavage of mesotrione followed by a reduction of the nitro group. This could explain the almost immediate formation of AMBA; (ii) a major pathway leading to AMBA via a reductive pathway of the amino group. Several metabolites were formed before being transformed into AMBA. The formation of these metabolites and their degradation will delay the appearance of AMBA. This may explain the increase in AMBA concentration after $60 \mathrm{~h}$ of incubation, this time corresponding to the disappearance of the two identified metabolites 1 and 2 (data not shown). Therefore a similar biodegradation pathway of mesotrione was observed with the two isolated Bacillus strains: 3B6 and Mes11. Nevertheless, the identification of the last two metabolites detected with Mes11 is under investigation and would allow understanding in more details the fate of mesotrione.

As sulcotrione, another member of the triketone family had a chemical structure closely resembling that of mesotrione, the capacity of the isolates to degrade this molecule was also tested. No degradation of sulcotrione was observed with either strain, underlining the substance-specificity of the Bacillus sp. isolated in our study. This suggests that the Mes 11 strain could attack the mesotrione at the level of the benzoyl 4-substituent for degradation, and highlights the importance of this position on the molecule not only for its herbicidal activity (Lee et al., 1998; Mitchell et al., 2001) but also for its remanence.

Studies to obtain further data on the mesotrione degradation pathway with Mes 11 and identify the degrading gene involved in mesotrione biotransformation are in progress in our laboratory.

\section{Acknowledgments}

The authors thank M. Debote of INRA of Clermont-Ferrand (Crouel) for use of the experimental field. They also thank Tiffany Charbouillot for her assistance in HPLC analyses.

\section{References}

Ait Tayeb, L., Lefevre, M., Passet, V., Diancourt, L., Brisse, S., Grimont, P.A.D., 2008. Comparative phylogenies of Burkholderia, Ralstonia, Comamonas, Brevundimonas and related organisms derived from $r p o \mathrm{~B}, g y r \mathrm{~B}$ and $r \mathrm{rs}$ gene sequences. Research Microbiology 159, 169-177.

Alferness, P., Wiebe, L., 2002. Determination of mesotrione residues and metabolites in crops, soil, and water by liquid chromatography with fluorescence detection. Journal of Agricultural and Food Chemistry 50, 3926-3934.

Altschul, S.F., Madden, T.L., Schaffer, A.A., Zhang, J., Zhang, Z., Miller, W., Lipman, D.J., 1997. Gapped BLAST and PSI-BLAST: a new generation of protein database search programs. Nucleic Acids Research 25, 3389-3402.

Batisson, I., Pesce, S., Besse-Hoggan, P., Sancelme, M., Bohatier, J., 2007. Isolation and characterization of diuron-degrading bacteria from lotic surface water. Microbial Ecology 54, 761-770.

Bending, G.D., Lincoln, S.D., Sørensen, S.R., Morgan, J.A.W., Aamand, J., Walker, A 2003. In-field spatial variability in the degradation of the phenyl-urea herbicide isoproturon is the result of interactions between degradative Sphingomonas spp. and soil pH. Applied and Environmental Microbiology 69, 827-834.

Bonnet, J.-L., Bonnemoy, F., Dusser, M., Bohatier, J., 2008. Toxicity assessment of the herbicides sulcotrione and mesotrione toward two reference environmental microorganisms: Tetrahymena pyriformis and Vibrio fischeri. Archives of Environmental Contamination and Toxicology 55, 576-583.

Cetkauskaité, A., Grigonis, U., Beržinskiené, J., 1998. Biodegradation: selection of suitable model. Ecotoxicology and Environmental Safety 40, 19-28.

Chaabane, H., Vulliet, E., Calvayrac, C., Coste, C.-M., Cooper, J.-F., 2008. Behaviour of sulcotrione and mesotrione in two soils. Pest Management Science 64, 86-93.

Crecchio, C., Curci, M., Pizzigallo, M.D.R., Ricciuti, P., Ruggiero, P., 2001. Molecular approaches to investigate herbicide-induced bacterial community changes in soil microcosms. Biology and Fertility of Soils 33, 460-466.

Cullington, J.E., Walker, A., 1999. Rapid biodegradation of diuron and other phenylurea herbicides by a soil bacterium. Soil Biology and Biochemistry 31 , 677-686.

Dejonghe, W., Berteloot, E., Goris, J., Boon, N., Crul, K., Maertens, S., Höfte, M., De Vos, P., Verstraete, W., Top, E.M., 2003. Synergistic degradation of linuron by a bacterial consortium and isolation of a single linuron-degrading Variovorax strain. Applied and Environmental Microbiology 69, 1532-1541.

Durand, S., Amato, P., Sancelme, M., Delort, A.-M., Combourieu, B., Besse-Hoggan, P., 2006a. First isolation and characterization of a bacterial strain that biotransforms the herbicide mesotrione. Letters in Applied Microbiology 43, 222-228. 
Durand, S., Légeret, B., Martin, A.-S., Sancelme, M., Delort, A.-M., Besse-Hoggan, P., Combourieu, B., 2006b. Biotransformation of a triketone herbicide mesotrione by a Bacillus strain. Metabolite profiling using liquid chromatography/electrospray ionization quadrupole time-of-flight mass spectrometry. Rapid Commuspray ionization quadrupole time-of-flight mas
nications in Mass Spectrometry 20, 2603-2613

Dyson, J.S., Beulke, S., Brown, C.D., Lane, M.C.G., 2002. Adsorption and degradation of the weak acid mesotrione in soil and environmental fate implications. Organic compounds in the environment. Journal of Environmental Quality 31, 613-618.

El Fantroussi, S., 2000. Enrichment and molecular characterization of a bacterial culture that degrades methoxy-methyl urea herbicides and their aniline derivatives. Applied and Environmental Microbiology 66, 5110-5115.

El Fantroussi, S., Verschuere, L Verstraete W. Top, E. M. 1999. Effect of phenylurea herbicides on soil microbial communities estimated by analysis of 16SrRNA gene fingerprints and community-level physiological profiles. Applied and Environmental Microbiology 65, 982-988.

Heikinheimo, A., Lindström, M., Korkeala, H., 2004. Enumeration and isolation of cpe-positive Clostridium perfringens spores from feces. Journal of Clinical Microbiology 42, 3992-3997.

Heuer, H. Smalla, K, 1997. Application of denaturing gradient gel electrophoresis and temperature gradient gel electrophoresis for studying soil microbial communities. In: van Elsas, J.D. (Ed.), Modern Soil Microbiology. Marcel Dekker, New York, pp. 353-373.

Holmes, A.., Tujula, N.A., Holley, M., Contos, A., James, J.M., Rogers, P., Gillings, M.R., 2001. Phylogenetic structure of unusual aquatic microbial formations in Nullarbor caves, Australia. Environmental Microbiology 3, 256-264.

Ibekwe, A.M., Papiernik, S.K., Yang, C.-H., 2004. Enrichment and molecular characterization of chloropicrin- and metam-sodium-degrading microbial communities. Applied and Environmental Microbiology 66, 325-332.

Kopczynski, E.D., Bateson, M.M., Ward, D.M., 1994. Recognition of chimeric smallsubunit ribosomal DNAs composed of genes from uncultivated microorganisms. Applied and Environmental Microbiology 60, 746-748.

Lane, D.J., 1991. 16S/23S rRNA sequencing. In: Stackebrandt, E., Goodfellow, M. (Eds.), Nucleic Acid Techniques in Bacterial Systematics. John Wiley \& Sons, Inc., New York, NY, pp. 115-148.

LeBlanc, P.M. Hamelin, R.C., Filion, M., 2007. Alteration of soil rhizosphere communities following genetic transformation of white spruce. Applied and Environmental Microbiology 73, 4128-4134.
Lee, D.L., Knudsen, C.G., Michaelay, W.J., Chin, H., Nguyen, N.H., Carter, C.G. Cromartie, T.H., Lake, B.H., Shribbs, J.M., Fraser, T., 1998. The structure-activity relationships of the triketone class of HPPD herbicides. Pesticide Science 54 377-384

Maidak, B.L., Cole, J.R., Parker Jr., C.T., Garrity, G.M., Larsen, N., Li, B., Lilburn, T.G. McCaughey, M.J., Olsen, G.J., Overbeek, R., Pramanik, S., Schmidt, T.M. Tiedje, J.M., Woese, C.R., 1999. A new version of the RDP (ribosomal database project). Nucleic Acids Research 27, 171-173.

Mitchell, G., Bartlett, D.W., Fraser, T.E.M., Hawkes, T.R., Holt, D.C., Townson, J.K. Wichert, R.A., 2001. Mesotrione: a new selective herbicide for use in maize. Pest Management Science 57, 120-128.

Pesce, S., Fajon, C., Bardot, C., Bonnemoy, F., Portelli, C., Bohatier, J., 2006. Effects of the phenylurea herbicide diuron on natural riverine microbial communities in an experimental study. Aquatic Toxicology $78,303-314$.

Pesce, S., Bardot, C., Lehours, A.-C., Batisson, I., Bohatier, J., Fajon, C., 2008. Effects of diuron in microcosms on natural riverine bacterial community composition: new insight into phylogenetic approach using PCR-TTGE analysis. Aquatic Sciences $70,410-418$.

Rousseaux, S., Hartmann, A., Soulas, G., 2001. Isolation and characterisation of new Gram-negative and Gram-positive atrazine degrading bacteria from different French soils. FEMS Microbiology Ecology 36, 211-222.

Tringe, S.G., von Mering, C., Kobayashi, A., Salamov, A.A., Chen, K., Chang, H.W. Podar, M., Short, J.M., Mathur, E.J., Detter, J.C., Bork, P., Hugenholtz, P., Rubin, E.M., 2005. Comparative metagenomics of microbial communities. Science 22, 554-557.

Turnbull, G.A., Ousley, M., Walker, A., Shaw, E., Morgan, J.A.W., 2001. Degradation of substituted phenylurea herbicides by Arthrobacter globiformis strain D47 and characterization of a plasmid-associated hydrolase gene, puhA. Applied and Environmental Microbiology 67, 2270-2275.

Watanabe, K., Kodama, Y., Harayama, S., 2001. Design and evaluation of PCR primers to amplify bacterial $16 \mathrm{~S}$ ribosomal DNA fragments used for community fingerprinting. Journal of Microbiological Methods 44, 253-262.

Weisburg, W.G., Barns, S.M., Pelletier, D.A., Lane, D.J., 1991. 16S ribosomal DNA amplification for phylogenetic study. Journal of Bacteriology 173, 697-703.

Zhou, J., Xia, B., Huang, H., Treves, D.S., Hauser, L.J., Mural, R.J., Palumbo, A.V. Tiedje, J.M., 2003. Bacterial phylogenetic diversity and a novel candidate division of two humid region, sandy surface soils. Soil Biology and Biochemistry 35 , 915-924. 